RODERICK SPRAGUE

\section{The Literature and Locations of the Phoenix Button}

\section{ABSTRACT}

Brass military buttons with the figure of a phoenix bird are reported with great regularity from the West Coast of the United States. In spite of the excellent previous research and published conclusions of Emory Strong, there is a wealth of misinformation still being published. The literature, including both historical data and speculation on the original source of the buttons as well as site reports listing such buttons, is assembled and summarized, essentially an annotated bibliography with locational maps, as an additional step in the analysis of these distinctive artifacts. A bipolar distribution - involving burial caches and body ornamentation on the lower Columbia River and use as buttons in mission sites of California - is suggested, but as yet there is a dearth of research tying the two areas together. New directions for additional research include locating unreported buttons, developing distributional studies, verifying the theories of origins, and determining trading patterns.

\section{Introduction}

A brief summary of the current theory on the origin of the phoenix buttons is necessary for a clear understanding of the annotations and research questions being asked. Very briefly, the theory is that the buttons were made for Haitian troop uniforms during the reign of Christophe I (1811-1820). Strong (1975) has identified 3 types (flat buttons with only the bird, flat type with a cannon and mortar under the bird, and ball shaped buttons with only the bird), 3 styles (mainly differences in the flames and nest under the bird), 2 sizes (types I and II are $25 \mathrm{~mm}$ and $15 \mathrm{~mm}$ [ $1 \mathrm{in}$. and $0.6 \mathrm{in}$.], type III are $17 \mathrm{~mm}$ and $13 \mathrm{~mm}$ [ $0.7 \mathrm{in}$. and $0.5 \mathrm{in}]$ ), and 18 regimental numbers $(1-10,14,20$, and 25-30). On the basis of back marks found only on the largesize, ball-shaped buttons, it is assumed that all of them were made by Bushby of London. When Christophe committed suicide in 1820 , the buttons became surplus and through some, as yet unknown, process were traded to Hawaii, up the
California coast, and then brought to Nathaniel Wyeth's trading post on Sauvies Island near modern day Portland, Oregon (Strong 1975), not necessarily in that order.

This work is not a repeat of Emory Strong's theory of origins and copious illustrations. Any serious researcher should already have his 1960 and 1975 articles in hand and should not need a redundant set of illustrations.

Written works on the phoenix button, including archaeological site reports listing them as artifacts, are surprisingly numerous considering the specialized nature of the subject. Since the first newspaper article in Portland, Oregon in 1928 (Church 1928), the literature has been highly speculative and dominated by amateur archaeologists, amateur historians, and button collectors. The major division, however, has not been between groups of specialists but between the $\mathrm{Pa}$ cific Northwest and California including both archaeologists and historians. There has been virtually no communication between the two areas over a 50 year period because all of the site specific literature has been in regional sources. The only thing uniting the two areas has been the button collecting researchers east of the continental divide.

This annotated bibliography, with locational maps for the Northwest (Figure 1) and California (Figure 2), is offered for four reasons; first to aid other researchers in locating and evaluating sources, second to serve as the beginning of a detailed distributional study, third to solicit additional references and locational information that might help others in the making of such distributional studies, and fourth, perhaps this bibliography will lead to the answering of real anthropological questions such as those proposed below. For example such studies could lead to establishing the identity of the ship or ships bringing the buttons and perhaps even the trading stops made along the coast such as Gould (1994b) has already suggested for Hawaii.

A manuscript version of this bibliography was sent to a number of the listed authors, plus a few other researchers, all of whom are listed in the 
BRITISH COLUMBIA

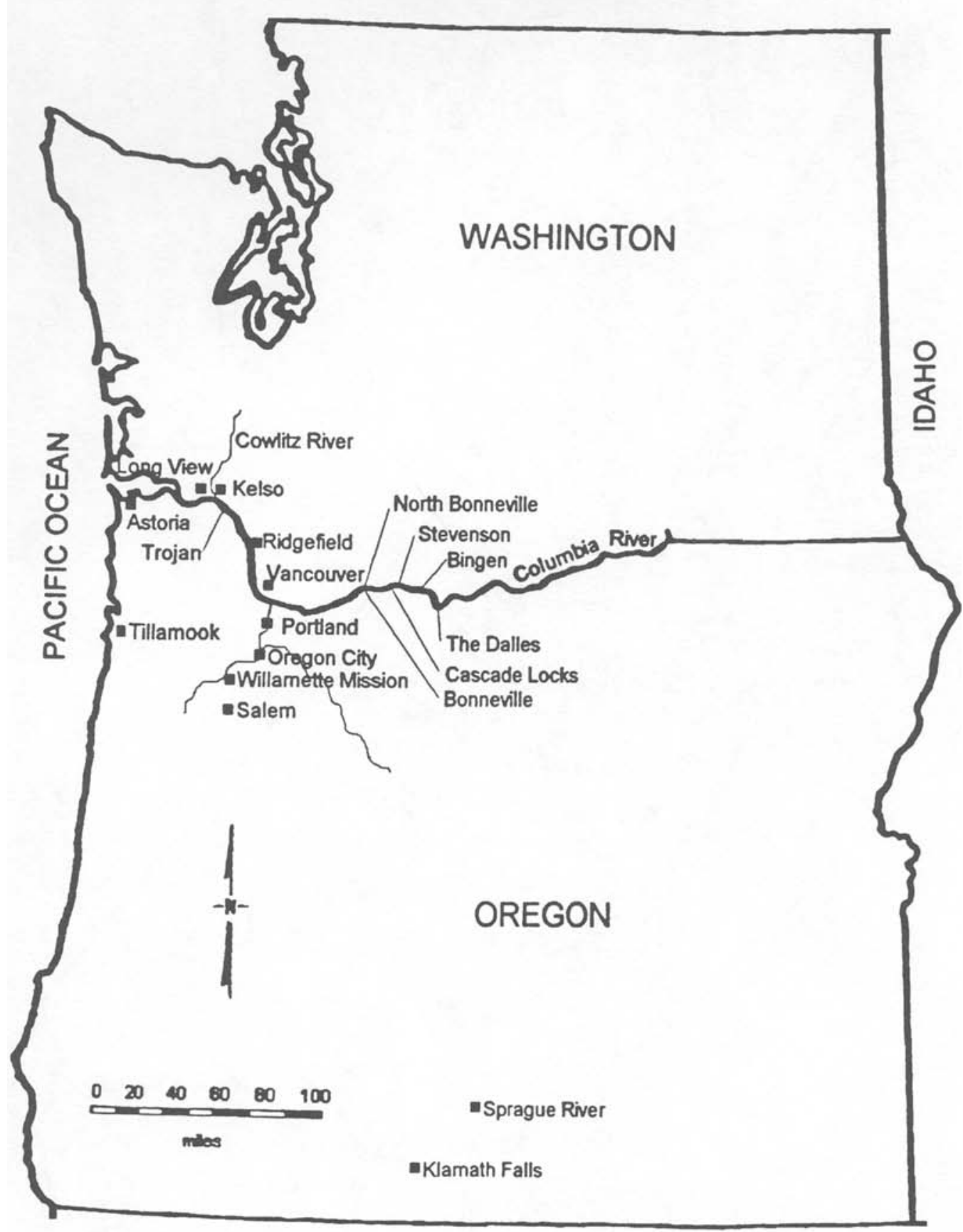

CALIFORNIA

FIGURE 1. Map of the Pacific Northwest showing sites that have produced phoenix buttons. 


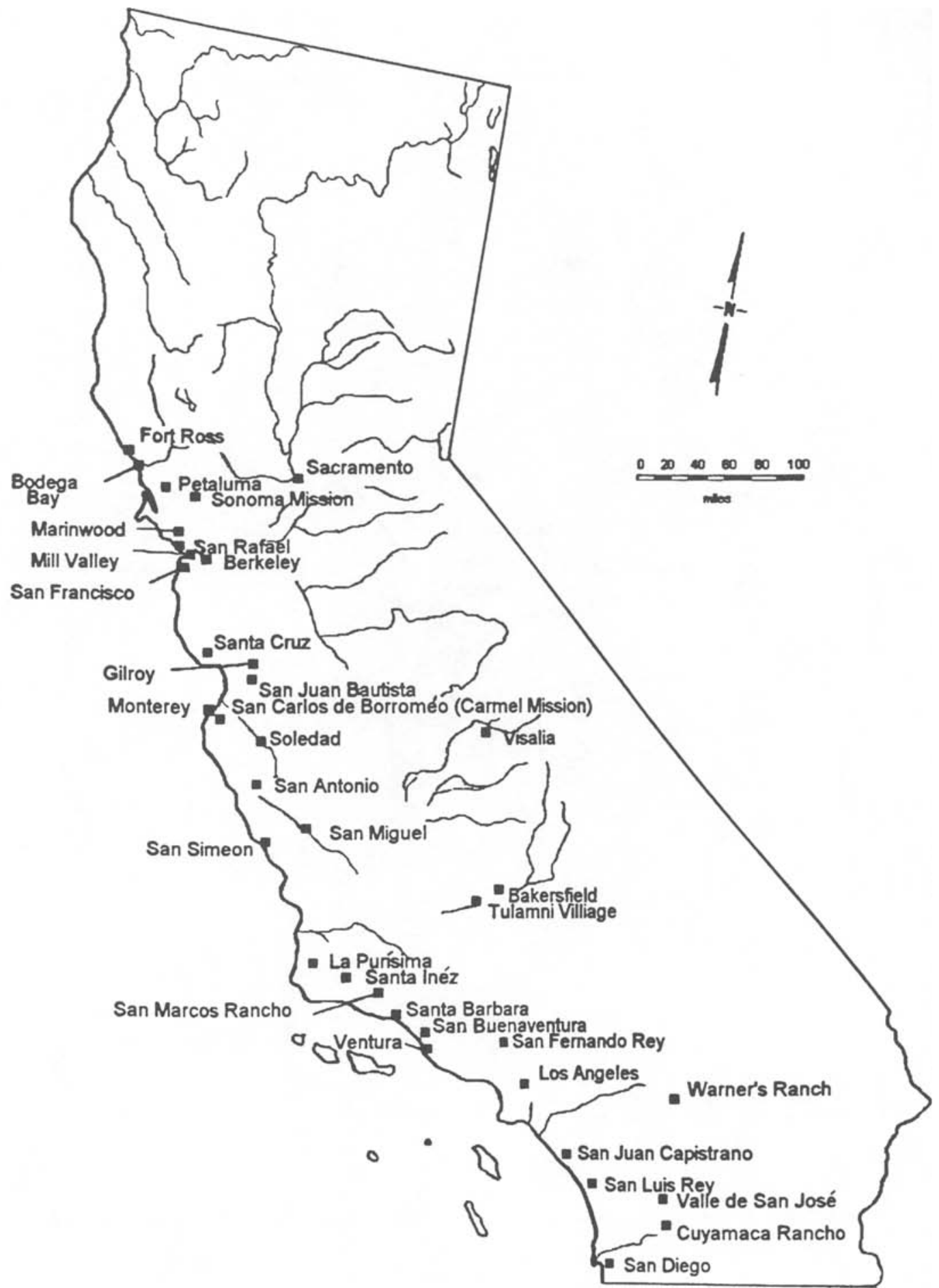

FIGURE 2. Map of California showing sites that have produced phoenix buttons. 
acknowledgments. In addition to the many new references and corrections provided by these individuals, David Brauner suggested numerous questions concerning future research. With his permission, this series of questions is listed with the hope that it will "help stimulate further inquiry on this most interesting topic" (David R. Brauner 1991, pers. comm.).

The paraphrased questions are: 1) has there been a systematic search of contemporary records to find written documentation of Wyeth's material goods traded on the lower Columbia? 2) do documents dealing with Wyeth's western business ventures exist other than his journals? 3) have the Hudson's Bay Company records been systematically searched for mention of Wyeth's activities and trade goods? 4) do business records still exist for the Bushby company in addition to business directories? 5) how complete are the Haitian archives dealing with the reign of King Christophe? 6) what archives might contain "nuts and bolts" documents of the Christophe government? 7) do detailed records exist for exports out of England or into Haiti at the time in question? 8) are there records of surplus uniform sales in Haiti? 9) do ships logs, manifests, or insurance records exist for the Wyeth venture? 10) how does the distribution in California [or Hawaii] contrast with that of the Northwest and why? (11) did Wyeth or others import uniforms and buttons into California and the American Southwest? 12) what insights into the politics of western trade might be gained from the study of the buttons?

Surprisingly, answers to some of these questions, such as 10, are beginning to appear through this preliminary review of the literature. Also the evidence coming from Hawaii is encouraging (Gould 1994a, 1994b) with four buttons found; two on Oahu (Gould 1994a) and two on Kauai (McCoy 1972). One reviewer also suggested that how the various native groups in California, the Columbia River, and Hawaii differed in their acceptance and use of the buttons should be investigated. The vast majority of these questions however are still only questions with no answers.

Since so little research has been done on phoenix buttons it is essential to clearly state what this article is not attempting to do. It is not a theoretical work explaining were and when phoenix buttons were distributed, it is an effort to find the sites and their buttons so such research can be done. It is not a complete list of all phoenix buttons, this will take extensive travel and time with the cooperation of innumerable professional archaeologists, amateur collectors, mission and fur trade historians, and button collectors. It is not an attempt to assign dates or ages to buttons or sites, this must be done by regional experts and is clearly beyond the scope of this work. Until such surveys are made and the raw data collected, tables of buttons showing their locations and possible dates are premature and meaningless. But to suggest that this work should first be published in regional journals is to relegate the study to its current level of stagnation and lack of national notice of significance. Finally, this is not a report on completed research but presents suggestions for possible areas of future research.

The references contain more information than called for in the Historical Archaeology Style Guide to aid those preparing any style of bibliography or making interlibrary loan requests. More will be said later in the annotations and conclusions about the capitalization of the word "phoenix." Page numbers for the unpaginated journal Screenings (Portland) have been provided and are always 1 through 4 . Likewise numbers have been provided for the Diamond Head Liner (Honolulu). All of the references cited in this introduction and in the conclusions are contained in the bibliography section. The page numbers listed in brackets following some references are the pertinent pages when a source is not exclusively devoted to phoenix buttons.

The annotations are directed toward locating the buttons today; locating the site of origin; indicating button type, style, size, and regiment; 
and clearly indicating the level of reliability of the source. This last item may be indicated by statements concerning the errors within a source. It is not the intent to be "mean spirited" but simply to indicate the level of accuracy as an indicator of overall reliability.

The classification code for the types of buttons follows Strong (1975) but in a condensed form: I, II, and III are types; 1, 2, and 3 are styles; s and b stand for small and big (" $l$ " [el] for large is too easily confused with the number " 1 " [one]); and the final number is the regimental number. A missing element means that it could not be determined. For example, Ib5 would mean Type I, large size, regimental number 5; but in this case, the style could not be determined from that bibliographical reference or any other source. When a button has no known size, a dash is inserted to separate the style number from the regimental number, for example I2-5. In retrospect, it would have been easier for all if Strong had called either his types or his styles A, $\mathrm{B}$, and C. For example, a I1s8 is easily confused with a IIs8. The use of A, B, and C for I, II, and III is seriously suggested here (but not used here) as a standard system for easier and quicker laboratory analysis. It is also suggested that any recorded or published description should include any modifications such as drilled holes, wear patterns, damage, and the condition (or absence) of the attachment loop. The rare back mark, as discussed under specific references, should also be noted.

Site numbers are given in the discussion as presented in the source. For example, sites can be designated as 45-FR-36, 45 FR 36, 45FR36, or the same series with Fr or fr. California sites can be Smithsonian site designations with an initial 4 (also 04) or with CA. California (and some Oregon) county designations are three letters rather than the normal two with almost any combination of capitalization. Islands named for people are presented in cartographic style without the apostrophe-Millers, Sauvies, and Sullivans.

The reliability of button type determinations is quite variable and all should be checked against the actual buttons before any final conclusions are made for or from distributional studies. Also because all of Strong's earlier publications used a different breakdown, types other than I1 should be checked against his 1975 publication. In accordance with tradition, lists of buttons are presented in order of the regimental number with large buttons preceding small. When a series of regimental numbers is listed, a number in parentheses indicates the quantity of the preceding sample when it is greater than one.

Emory Strong planned to compile an inventory of button types when he made an effort to determine what regimental numbers had been made and what specimens had been traded into the western United States (Livingston 1964). This effort is being continued and expanded by Frank Buehler of Hillsboro, Oregon. Emory Strong's collection was donated to the Columbia River Gorge Interpretive Center, Stevenson, Washington and should have been available for research in 1994.

There are a few major or significant finds that as yet have not been published and are worthy of brief mention; however, by no means is this list complete. Donald P. Heldman (1988, 1991, pers. comm.) excavated a Ilb29 from the American Millwright's home/workshop (ca. 1820-1850) at the Mill Creek site $(20 \mathrm{CN} 8)$, near Mackinaw City, Michigan. This represents one of the most easterly, authenticated excavation of a phoenix button. Steven Dietz (1989, pers. comm.) recently obtained a large sample, reputedly found on pre-1925 Swan Island in Portland, Oregon. The Cooper-Molera Adobe in Monterey has had 15 buttons recovered including: I1b-14, 20, 27, 29; I1s-1, 2, 7(2), 8, 25(2), 28, 30; Is14; and Is29 (Glenn J. Farris 1989, pers. comm.). The Marshall-Seaman collection in the Oregon State Museum of Anthropology, University of Oregon contains 18 buttons probably from Fountain Bar, Washington, 14 miles upriver from the mouth of the John Day River (Don E. Dumond 1992, pers. comm. via Rick Minor pers. comm. 1992). Included are: Ilb-1, 2 (2), 8 (2), 25 (2), 28; I1s5 (2), 7, 8, 14, 27 (3); I2b27; I2b29. The cata- 
logue numbers fall between 2-7685 and 2-7705 (except 2-7688, 2-7693, and 2-7698). The Yakima Valley Museum of Yakima, Washington has six buttons including I1bl(2), 4, 7, and I1s5 and 7. An anonymous reviewer reported a button found in 1976 in the Plaza Hotel site, San Juan Bautista. A ball type (type IIIb2) was recovered in 1992 from a slave cabin at Andrew Jackson's The Hermitage, near Nashville Tennessee (Larry McKee 1997, pers. comm.). This is the most easterly, authenticated excavation of a phoenix button. Most recently, during the 1997 field season, four buttons were reported (including a Ilb4 and a Ilb8) from Anchorage in an apparent Russian context (J. David McMahan 1997, pers. comm.). Other unpublished notices of buttons are also mentioned in several appropriately related annotations.

\section{THE BIBLIOGRAPHY}

\section{AdAM, ChuCK}

1968 The Phoenix Button. Central States Archaeological Journal 15(1):35. Springdale, AR.

This report of an amateur find of a I1b28 button at Aldrich Point near Astoria, Oregon, includes an excellent illustration. See also Minor (1989).

Aikens, C. Melvin

1993 Archaeologyof Oregon. Bureau of Land Management, Portland.

Two buttons, I1b1 and I1b8, found in the Roadcut site at The Dalles are illustrated. The figure is obviously up-sidedown as the phoenix buttons are on the right not the left. These are not the same buttons reported by Cole (1954) from The Dalles, yet Aikens calls it the Roadcut site which apparently is the same site as listed by Cole (1954) and Cressman and others (1960) as [35]-WS-4 . This work does not capitalize phoenix.

ANonymous

See: California Historical Society, Hobbies, Oregonian, and Screenings.

Axford, Harold

1937 Indian Grave Yields French Haitian Army Buttons of Unusual Design. Oregon Journal 33(41):11; 11 April. Portland.
An "Indian grave on the Clackamas river" near Gladstone, Oregon, produced 17 phoenix buttons, 15 large and 2 small. At the time of the article the buttons were owned by Nelly Church. These were probably the buttons dug by her grandparents (John W. Church 1989, pers. comm.). The button was erroneously described as worn by Napoleon's Haitian troops. See also Church (1928).

Bourdeau, LARRY

1985 A "Phoenix" Button at [sic] Found in Santa Cruz. Society for California Archaeology Newsletter 19(1):11. Fullerton.

One button, a I1b4, was recovered in 1984 at CA-SCr-24 in Santa Cruz, California near Mission Santa Cruz. Also published in the Society for Historical Archaeology Newsletter in virtually identical form (Schumacher 1985). See also McHugh (1987).

BRown, DoRothy FosTer

1957 Button Notes. Hobbies 62(7):52-53. Chicago.

This is a brief retelling of the highly doubtful Napoleon theory of Harry Downie (MacLennan 1953) that the buttons were made for Napoleon with additional misinformation and a generalized drawing of a type I1-8.

1968 Button Parade. Reprint of 1942 edition. WallaceHomestead Book Company, Des Moines. [pp. 242243]

An historical overview of first the Napoleon theory and then the more widely accepted theory involving only Haiti. One simplified sketch of a I1-8 is included. The 1942 1 st edition, the 2 nd edition published in "ca. 1942" according to the National Union Catalog, and the 3rd edition of unknown date - all published in Chicago by the Lightner Publishing Co. - contain no reference to phoenix buttons. This edition is labeled as the 4 th edition, with the copyright still held by Lightner Publishing Co., the publishers of Hobbies magazine.

\section{CAlifornia Historical Society}

1954 News of the Society. California Historical Society Quarterly 33(1):76-92. San Francisco. [p. 87]

The news includes a secondary summary of a talk given to the Society by Robert F. Heizer, 12 November 1953 . It is reported that he described the general outline of the phoenix button history but implied that the buttons were manufactured in Connecticut and brought only to California. This work does not capitalize phoenix. 
Calver, William Louis, and Reginald Pelham Bolton

1950 History Written with Pick and Shovel. New York Historical Society, New York.

Strong (1974) says this work mentions Nelly Church and phoenix buttons, but as O'Brien (1970) points out, this is in error. Calver is mentioned as an informant by Church (1928) and Strong (1968).

CAMERON, Frank

1959 California's Wonderful One. National Geographic Magazine 116(5):571-617. Washington. [pp. 586588]

The retelling, in a popular national journal, of the discredited Downie theory of phoenix buttons being made for Napoleon (MacLennan 1953). This work does not capitalize phoenix.

CARrico, Richard L.

1982a Phoenix Buttons from the San Diego Presidio Chapel Complex Excavations. Manuscript, San Diego Historical Society, San Diego.

This is an excellent discussion of the Mexican trade restrictions and their effect on phoenix button distribution. Carrico has independently come to many of the same conclusions that Pilling (1950) reached thirty years earlier and that Pilling also did not publish. In addition to the sites in California listed in Pilling (1950) or other works earlier than Carrico, there are Ventura and several sites in San Diego County "including a site in Rancho Cuyamaca State Park, a site near Mission San Luis Rey on Ranch Guajome, and a site in Valle de San José near Lake Henshaw," as well as Warner's Ranch. The San Diego Presidio excavations yielded a sample of 19 buttons. All but two were I1 s including regimental numbers: 1, 2, 4 (6), 7 (3), 8, 20 (3), 25, 27, 28, and 30. Also found were I1b25, I12s1, and a large 25 which was otherwise indistinct. The buttons show wear patterns indicating their use as buttons, not simply as decorations. See also Ezell (1968a, 1968b, 1976).

1982b Phoenix Buttons from the San Diego Presidio Chapel Complex Excavations. In Approaches to Historical Archaeology: The Case of the Royal Presidio of San Diego, edited by Stephen A. Colston, pp. 2-3 [abstract]. San Diego History Research Center, San Diego State University, San Diego.

This is only the abstract of a presented paper with exactly the same title as the manuscript listed above. It does not have the same theoretical and historical approach, hence the presented paper probably was not as complete as the published version.
CAywood, Louis R.

1955 Final Report Fort Vancouver Excavations. Manuscript, National Park Service, Region Four, San Francisco. [p. 48]

The only professional archaeological mention of phoenix buttons prior to this work is Strong, Schenck, and Steward in 1930. Two buttons, apparently Is types, were found here at the major Hudson's Bay Company site of Fort Vancouver in Vancouver, WA. See Ross (1976) for additional Fort Vancouver area references.

Church, C. Corbly

1928 Clackamas Indian Grave Yields Buttons of Haitian Soldier. Sunday Oregonian 47(33):magazine 2, 7; 12 August. Portland.

This newspaper article was written by the 23 year-old (born 12 January 1905) and eldest son of button expert Nelly Church. The surprising thing about it is that it sets out the basic theory of the Haitian origin of the phoenix button many years before anyone else wrote on the subject. Some ideas such as the suggested United States manufacture of the buttons, have been superseded but these are only minor points in the total discussion. Illustrations include Christophe; one of his coins, obverse and reverse; the palace citadel; the location of a cache found "a few years ago" along the Clackamas River near Gladstone, Oregon; and four buttons apparently from the same location. Three of the buttons appear to be type I, one type II, and all of several different regimental numbers. The claim is made that the buttons had imprints in the back, "Best Quality" and "Imperial Standard." Strong (1975) shows one example of the first but does not include the second, thus this is the only mention in the literature of such a back-mark. Strong in his works consistently misspells Corbly as Colby and Lockley (1947) misspells it as Corbley. Seaman (Pilling 1950:note 28) lists Corbly's age as too young by 5 or 6 years. For more on Clackamas River see Axford (1937), Strong (1974), and Woodward and Beals (1980).

\section{Church, Nelly Ely}

1951 Tribes and Traders and Eagles. Oregon State Button Bulletin 1(1):16. Salem.

Besides illustrating four Ib3 buttons of unknown provenience, Mrs. Church (1885-1959) makes the startling and unsubstantiated statement that "We know there must have been over 600,000 of these buttons fabricated. . .."The author's first name is Nelly, not Nellie, as spelled by Strong (1958a:1, 1959:215) and Livingston (1964:9). The article is signed simply as N. E. C. 
Cole, David L.

1954 A Contribution to the Archaeology of The Dalles, Oregon. Unpublished Master's thesis, Department of Anthropology, University of Oregon, Eugene. [p. 76]

Burial 1, site [35]-WS-4, at Fivemile Rapids, near The Dalles, Oregon, contained four phoenix buttons of which the three illustrated in Plate XXVI-B 10, 11, and 12, are all small size. Since these seem to be in the same photographs as Cressman (1960:99) all four buttons are probably also illustrated at a much smaller scale in Plate XXVI-A. This source has more information on the burials than Cressman (1960) but neither have any text concerning the buttons. Rick Minor (1992, pers. comm.) inspected the buttons in the Oregon State Museum of Anthropology, University of Oregon, Eugene and reports that they are all $\mathrm{I} 1 \mathrm{~s}$ with regimental numbers 5 (cat. no. WS4 HI-18), 6? (badly worn)(cat. no. WS4 HI-14), 14 (no cat. no.), and 27 (cat. no. WS4 HI-16). These are not the same buttons from The Dalles as illustrated by Aikens (1993).

\section{Colwell, Wayne A.}

1963 Phoenix Buttons. Journal of the Company of Military Historians 15(2):56. Washington. Reprinted 1964 in National Park Service News and Views May, p. 8. Washington.

The recovery of two buttons at La Purísima Mission in 1962 by California State Parks' archaeologists is described. The information presented is obviously based on Strong (1960). Finds made at Fort Ross are mentioned. This is the first reference to mention finds on the Plains but lists no sites or references. There is one illustration of a I1b9. The two are not the same buttons as mentioned by Pilling (1950:4). See also Deetz (1963).

Corning, Howard MCKINLEy (EDITOR)

1956 Dictionary of Oregon History. Binfords \& Mort, Portland. [p. 196]

A largely erroneous paragraph that lists Seaman (1960) as the only source. See also Thompson (1968).

\section{Crawford, Cliff}

1986 Editor's Note. Skamania County Heritage 15(2):3. Stevenson, WA.

An editorial preface to the unauthorized 1986 reprints of Strong (1975), and perhaps Strong (1960), in which one photograph is called "photographs" and Strong is listed as having published only two articles on phoenix buttons! Except for the journal names and the year of publication of one, no information is given concerning the original publications including place of publication, dates, volume, issue, pages, or copyright holder.

Cressman, L. S., in collaboration with David L. Cole, Wilbur A. Davis, Thomas M. Newman, and Daniel J.

SCHEANS

1960 Cultural Sequence at The Dalles, Oregon, A Contribution to Pacific Northwest Prehistory. Transactions of the American Philosophical Society ns. Vol. 50, Part 10. Philadelphia. [pp. 75, 99]

Appendix B, consisting solely of a table of burial artifacts from site [35]-WS-4, near The Dalles, Oregon, (taken from Cole 1954:76-77), lists four phoenix buttons recovered from Burial 1. Perhaps all four buttons are illustrated illegibly in Figure 56a and two or three, at a larger scale, can be seen in Figure 56b. The two that can be identified are a I1s14 and a I1s27. For slightly more detail see Cole (1954).

DeETZ, JAMES J. F.

1963 Archaeological Investigations at La Purísima Mission. Department of Anthropology and Sociology, University of California, Los Angeles, Archaeological Survey, Annual Report 1962-1963, pp. 161-240. Los Angeles. [pp. 198, 201, 208, 239] Reprinted 1978 in Historical Archaeology: A Guide to Substantive and Theoretical Contributions, edited by Robert L. Schuyler, pp. 160190. Baywood Publishing, Farmingdale, NY. [pp. 184-185, 187-188]

This source includes the very brief mention of two buttons found at site CA-SBa-520, La Purísima Mission, accompanied by a totally illegible illustration showing two buttons, a large and a small. The original 1963 edition lists both of the author's middle initials, the reprint lists only $\mathrm{F}$, and more recent publications list neither. See also Colwell (1963) and Pilling (1950:4).

Dietz, STEPhen A.

1976 Echa-tamal, A Study of Coast Miwok Acculturation. Unpublished Master's thesis, Department of Anthropology, San Francisco State University, San Francisco. [pp. 144, 188, 267, 283]

Using the two standard works by Strong $(1960,1975)$, Dietz describes two buttons as I1 b26 and I1 b27 from site 04 Mrn-402, Marin County, California. The button in the illustration is virtually illegible. He also mentions that phoenix buttons have been found at two other Marin County sites, Mill Valley (04-Mrn-14) and Olompali (04-Mrn-138), as described by Slaymaker(1974, 1977).

Doolittle, Robert A.

1942 Queries [No. 5]. Mariner's Mirror 28(1):87. Cambridge, England. 
The report of a I1b5, found on the north shore of Monterey Bay, near Santa Cruz, California. Pilling (1950:note 41) contains correspondence and details of this 1940 find that have never been fully published. Includes one drawing each of the face, back, and side of this now lost button.

Ezell, Paul H.

1968a A Landscape of the Past: The Story of the Royal Presidio. Journal of San Diego History, 14(4):5-32. San Diego. [p. 29]

In this fairly lengthy article, the only mention of phoenix buttons is in relation to the artifacts in graves thus: “. .. a few buttons (including a Phoenix button of the time of Napoleon)...."

1968b Report on the Presidio Excavations, 1967. Journal of San Diego History, 14(2):28-30. San Diego. [p. 30]

At the Presidio of San Diego, a button was found outside the south wall of the church and another one was found outside the south wall of the nave. No description is provided. Rintoul (1965) is used as a source for historical context thus the now rejected Napoleonic theory is suggested.

1976 The Excavation Program at the San Diego Presidio. Journal of San Diego History, 22(4):1-20. San Diego.

A I1s7 is illustrated (p. 14) and is in a list of items found since the last report that includes "Phoenix and ordinary buttons" (p. 16). See also Carrico (1982a, 1982b). Jack Williams, recently directing excavations at the Presidio of San Diego, also reports numerous phoenix buttons have been recovered at the site. Also in the San Diego area at the Mission de San Diego, two small buttons are on display from the 1976 excavations by Ray Brandes. These are I1s5 and I1s20.

FARNSWORTH, PAUL

1987 The Economics of Acculturation in the California Missions: A Historical and Archaeological Study of Mission Nuestra Senora de la Soledad. Ph.D. dissertation, University of California, Los Angeles. University Microfilms International, Ann Arbor [412, 414]

The text mentions that two phoenix buttons were found, but the illustration shows only that there was a large and a small.

FARRIS, GLENN J.

1981 Preliminary Report of the 1979 Archeological Monitoring of Excavations in the Rear Yards of the Sonoma Barracks, Toscana Hotel, and the Casa Grande, Sonoma State Historical Park, Sonoma, California.
Manuscript, Resource Protection Division, Department of Parks and Recreation, Sacramento. [pp. 13, 13a]

One button is mentioned as being found on footing stones at Sonoma Barracks dating ca. 1830s (Farris 1981:13) or more accurately 1836 (Glenn J. Farris 1989, pers. comm.). A single illustration shows one large and two small buttons: I1b28, I1s9, and I1s29. See also Felton and St. Louis (1977).

1986 Ethnohistoric Accounts of the Indians at San Simeon Creek. Appendix A to The Prehistory of San Simeon Creek - 5800 B.P. to Missionization, by Philip Hines, pp. 75-91. Manuscript, Resource Protection Division, Department of Parks and Recreation, Sacramento. [p. 90]

The two buttons as reported in Hines (1986:15) include a I3b6 and a I2b28. The Rancho San Simeon is an outlying ranch of Mission San Miguel Archangel. Farris notes that "The presence of the Phoenix buttons mixed with Indian artifacts and remnants of the early adobe buildings is consistent with an occupation of the $1830 \mathrm{~s}$ and 1840s."

1991a Archeological Testing inthe Neophyte Family Housing Area at Mission San Juan Bautista, California. Manuscript, Resource Protection Division, Department of Parks and Recreation, Sacramento. [p. 37, Figure 26]

A single I1s26 found in Room A-9 of the neophyte family housing is illustrated with one fair drawing. It also mentions this bibliography in its manuscript form. This is the same button as mentioned in the next item. See also Pilling (1950:11).

1991b Probing for the Neophyte Family Housing at Mission San Juan Bautista. Society for California Archaeology Newsletter 25(5):1, 3. Fullerton.

A single I1s 26 was found in Room A-9 of the neophyte family housing. See the previous item for more details and an illustration.

Felton, David L., and Cynthia St. Louis

1977 Sonoma Barracks: Archeological and Historical Investigations, 1976. Manuscript, Resource Protection Division, Department of Parks and Recreation, Sacramento. [pp. 99, 102-103]

A single example of a I1s25 from the East Yard of Sonoma Barracks is described and illustrated with reference to Strong (1975). See also Farris (1981). 


\section{FIXIT, Mr. (LoIS Myers)}

1950 Hunts Turn Up Relics. Oregon Journal 46(28):C9; 1 October. Portland.

Mr. Fixit is a regular column with letters (Galbraith 1950) and answers. Seaman (1946) is the only source used. He (she) says that several buttons have been found in Nebraska - a unique statement. The first introduction into the Northwest is given as "about 1835" and the United States is given as the place of manufacture. Two buttons are illustrated: I1b14 and I1s5. Mr. Fixit's real name was provided by Don Sterling of Portland.

FURNIS, LYNN

1989 Analysis of Buttons from Santa Inés Mission. In Santa Inés Mission Excavations 1986-1988, Julia Costello, pp. 201-207. Report to the sponsoring agency. [pp. 203-205] Published 1989 as Santa Inés Mission Excavations: 1986-1988. California Historical Archaeology No. 1. Coyote Press, Salinas, CA. [pp. 143-144]

One Is4 (cat. no. 342-324) is described with a fair illustration. It was found in an "1882-to-present context" (p. 205/ 143). The summary of Strong (1960 [1967 edition is referenced]) is concise and accurate but Strong (1975) is not used. The back loop would have been soldered or brazed but not "welded."

Galbraith, Howard

1950 Letter to Mr. Fixit. Oregon Journal 46(28):C9; 1 October. Portland.

This brief letter of inquiry is answered, in part, by columnist, Mr. Fixit. See Mr. Fixit (1950) for more details.

Gould, STEVE

1994a Unknown Variety of Rare Phoenix Button Found on Oahu. Hawaii Historical Bottle Collectors Club Diamond Head Liner January, pp. 5-10. Honolulu.

About 1990, Gould found a I3b26, missing the shank and badly split, on a southeast Oahu beach. He researched this regimental number, which was previously unknown to Strong (1975:76), through a combination of Laura Carter of Hawaii, a draft of this bibliography, and Frank Buehler of Oregon. He presents a summary of the usual Emory Strong data and mentions three other buttons found in Hawaii; the one reported by McCoy (1972), the one reported by Laura Carter as already noted under McCoy (1972), and "A third phoenix button may have come out of an old outhouse dug by Gary Lau in the Smith Street area of Honolulu, but this has yet to be positively confirmed." The last five of the six illustrations are taken from Strong (1965:Figure 1-
5) but the first one cannot be identified. Gould does not capitalize phoenix.

1994b Phoenix Button Mystery Solved. Hawaii Historical Bottle Collectors Club Diamond Head Liner February, pp. 5-6. Honolulu.

In contrast to the previous article suggesting that the Hawaiian phoenix buttons arrived on the Sultan, Gould has now concluded that they arrived on the May Dacre. Research included the use of the 1834 U. S. Consular Reports showing that the May Dacre stopped at Honolulu enroute to the Columbia River to unload "Hardware, Dry Goods \& Liquor."

Gurcke, Karl with Michael Bies, Thomas M. J.

Mulinski, AND Roderick Sprague

1981 Nez Perce National Historical Park Archaeological Excavations, 1979-1980, Part I: Burial Recovery and Monitoring. University of Idaho Anthropological Research Manuscript Series No. 70. Moscow. [p. 20, 33]

A $12 \mathrm{~b} 27$ was found in a mass of artifacts recovered out of context from a series of disturbed Nez Perce burials. The photograph on p. 33 is fair enough that the style details can be seen. In spite of this work being edited by the author of this bibliography, phoenix is capitalized. This is the furthest up the Columbia River system that a phoenix button has been recovered.

Hamilton, Geneva

1963 Site of Old Mission Rancho Adobe Building Uncovered. San Luis Obispo County Telegram-Tribune 95(112):magazine 4; 14 December. San Luis Obispo, CA.

"A number" of phoenix buttons from San Miguel Mission near Cambria were discovered at some undisclosed time in the past. Included is one illustration of a I $2 \mathrm{~b} 28$ and a I3b6. The Downie theory involving Napoleon (MacLennan 1953) is given with the additional embellishment of pirates taking the buttons before they reached Haiti!

1974 Where the Highway Ends. Williams Printing, Cambria, CA. [pp. 187, between 189-190]

The same misinformation as the preceding source is presented again. The quantity is described here as "several." The quality of reproduction of the same illustration is greatly improved.

HeIzer, Robert F.

1947 AnEarly 19th Century California(?)CopperMedallion. California Historical Society Quarterly 26(4):349350. San Francisco. 
There is nothing new in this comparative mention of the research note by Doolittle (1942). The question mark in parentheses is part of the original title. See also California Historical Society (1954).

1951 Notes on Phoenix Buttons. Manuscript No. 23, California Survey, Department of Anthropology, University of California, Berkeley.

This document contains six brief pages of notes and references plus a letter from Art Woodward to Heizer. Woodward mentions buttons at Tumacacori Mission, Arizona (Walker with Woodward 1947), Santa Barbara Mission, Carmel Mission, and the lower San Joaquin Valley (probably Elk Hills [Walker and Woodward 1947]), all in California. Woodward also mentions a "French" uniform in the San Joaquin valley," California, that he thought was a Haitian uniform that would have solved the mystery but he could not find the source of the rumor. See also comments on Woodward under Wilson (1985).

Hildebrant, William, and Pat Mikkelsen

1992 Prehistoric Adaptations in Southern Santa Clara Valley, California. Report to Caltrans, California Department of Transportation, Sacramento from Far Western Anthropological Research, Davis.

Two buttons, a I1s8 (97-73-151) and a I2s29 (90-73-623), were recovered from CA-SCA-308/H, near Gilroy in southern Santa Clara County, California. The ceramics suggested a date range of 1800 to 1840 (Julia Costello 1992, pers. comm.).

HiNes, PHILIP

1986 The Prehistory of San Simeon Creek-5800 B. P. to Missionization; Ancillary Studies by Glenn J. Farris, Michael F. Rondeau, Thomas Roger, Mark A. Roeder, Robert O. Gibson, and Ivan Strudwick. Manuscript, Resource Protection Division, Department of Parks and Recreation, Sacramento. [p. 15]

Two phoenix buttons found by the previous land owner, Lindy Bonomi, are mentioned from near San Simeon. The cover has " 5,800 " while " 5800 " is on the title page. See Farris (1986:90) within the same work for complete details.

\section{HOBBIES}

1948 “The Phoenix.” Hobbies 52(12):43-44. Chicago.

This brief article, containing much misinformation, is based on the pothunter collection of Sanford M. Lord of Kelso, Washington. One illustration shows 35 buttons of unstated provenience of various types, styles, and sizes but none of type III. Norma G. Seaman is mentioned but in a letter to Pilling (1950:note 26) he denies any authorship of this article. The anonymous author calls him Norman. An illustrated $13 \mathrm{~b} 7$ is said to have a wreath "engraved" (more likely stamped or cast) on the back. This may be the same wreathmarked button described by Strong (1968) as being mentioned to him by William Louis Calver and perhaps one of the three illustrated in Strong (1975).

Hoffman, J. J., AND Lester A. Ross

1975 Fort Vancouver Excavations-IX, Indian Trade Store. Manuscript, Fort Vancouver National Historic Site, Vancouver, WA. [pp. 130-133]

Four phoenix buttons were found in the excavation of the post1836 Indian Trade Store by the National Park Service at Fort Vancouver, in Vancouver, WA. Analysis by Ross lists these buttons as: I1s4, I1s5, I1s29, and I3b2(?). One sketch shows the shank attachment form. See Ross (1976) for additional sources from the Fort Vancouver area.

Hoover, Robert L., AND Julia G. Costello (editors)

1985 Excavations at Mission San Antonio, 1976-1978. University of California, Institute of Archaeology Monograph 26. Los Angeles. [pp. 69-70, 72]

Two buttons were recovered at Mission San Antonio in southcentral Monterey County, California, during the 1976-78 excavations. The fair drawing would indicate a I1s10 (cat. no. 438) and I3s29 (cat. no. 188). Table 36 must be in error with specimen number 29 listed as having a $9 \mathrm{~mm}$ diameter. This work does not capitalize phoenix.

Howard, Donald M.

1976 California's Lost Fortress, The Royal Presidio of Monterey. Antiquities Research Publications, Carmel, CA. [p. 21]

One button is mentioned but not described. A brief synopsis of the Strong (1960) thesis is also presented. The text is virtually identical to Kernohan (1971).

Howe, Carrol B.

1992 Unconquered Uncontrolled: The Klamath Indian Reservation. Maverick Publications, Bend, OR. [p. 45]

One completely illegible picture of five large and three small buttons is presented with no new information.

Howe, DANA

1978 Descriptive Catalog. In "Preliminary Archaeological Investigations at San Marcos Rancho (SBa 109), Archaeological Field Class, Spring, 1978," edited by 
Roderick J. McIntosh and Julia Costello, pp. 67-70. Manuscript, Department of Anthropology, University of California at Santa Barbara, Santa Barbara. [pp. 6768 , Plate 7]

A single button, a I1s4 (225-117), is well described, illustrated, and placed in perspective using Strong (1960). It is compared to the finds at La Purísima Mission (Deetz 1963) “... also located in the Santa Ynez [Inéz] hills ..." of California (p. 70)

Hulquist OR HULTQUist, CAROL

1978 See Kielusiak, Carol.

Jensen, Frederic C.

1968 Story Supplied. Oregon Journal 66(278):10; 29 January. Portland. Reprinted 1968 as Phoenix Buttons; Screenings 17(8):4. Portland.

This letter to the editor is a detailed response to errors in Thompson (1968). Additional information on Christophe, not found in other sources, is presented. Jensen mentions the finding of buttons in Haiti. He states that the Klamath County Museum, Klamath Falls, Oregon, has four buttons on display. This source, including the reprint, does not capitalize phoenix. The reprint has a brief introduction by the editor of Screenings plus very brief notes on Woodward (1967) and Strong (1968) and a reprint of a picture from Strong (1959).

JoHNSON, DAVid F.

1948 Uniform Buttons, American Armed Forces 1784-1948, 2 Vols. Century House, Watkins Glen, NY.

Button Type No. 1153 (Vol. I, p. 205; Vol. II, p. 88) shows a fireman's uniform button with a phoenix not unlike the ones on the Haitian buttons, but it also has "Phoenix Hose Company" over the top and "Instituted 1817" straight across in two lines below the phoenix. The back has "robinson jones \& co extra rich."

KeRnohan, Vivian

1971 Buttons. In "Archaeological Investigations of the Royal Presidio of Monterey," by Donald M. Howard, p. 7. Monterey County Archaeological Society Quarterly 1(2):1-12. Carmel, CA.

This work describes and illustrates one illegible button excavated at the Presidio of Monterey and includes a synopsis of the Strong (1960) thesis on origins. The text is repeated almost verbatim in Howard (1976:21). It is obviously not one of the buttons mentioned by Pilling (1950:3) from this site.
Kielusiak, CAROL

1978 Buttons from the Official's Quarters at Fort Ross. Manuscript, Resource Protection Division, Department of Parks and Recreation, Sacramento. [pp. 29-31]

A single I1b8 is described and sketched with a brief summary of Strong (1975). Written under her then-married name, Hultquist. The manuscript is typed as Hulquist with a penned in " $t$ " to read Hultquist. At least one other button was found in the 1990s (Glenn J. Farris, 24 January 1997, pers. comm.)

KirK, Myrle A.

1975 Buttons from the San Buenaventura Mission Site, 1974. In 3500 Years in One City Block, San Buenaventura Mission Plaza Project Archaeological Report, 1974, edited by Roberta S. Greenwood, pp. 295-363. Redevelopment Agency City of San Buenaventura, Ventura, CA. [pp. 349-353]

This is one of the best uses of the available information yet published. Kirk summarizes the state of our knowledge in 1975 and then categorizes the finds using Strong's (1975) types. She also explains where they were found and hence the cultural meaning of these finds from the area of Ventura, California. Ten are I1s with the following regimental numbers: 1, 2, 4 (2), 6, 7 (2), 8 (2), and 9; plus I1b25, Ilb26, I2b28, and IIlb2. Three have back markings showing an "o". In a personal communication to Kirk, Strong suggests that these are a die flaw.

1976 Buttons from the San Buenaventura Mission Site, 1975. In The Changing Faces of Main Street, edited by Roberta S. Greenwood, pp. 369-415. Redevelopment Agency City of San Buenaventura, Ventura, CA. [pp. 396-397]

Five additional buttons were excavated in 1975 at the San Buenaventura site. All are I 1 s except for one small size in such poor condition that nothing could be determined. Regimental numbers determined were: 6, 9 (2), and 27. Two additional buttons were recovered in 1990 during monitoring of the Ventura Mission site (CAVEN-87). They were a I1b4 and an illegible small button (Roberta S. Greenwood 1991, pers. comm.).

\section{Lancaster, Samuel Christopher}

1915 The Columbia, America's Great Highway through the Cascade Mountains to the Sea. S. C. Lancaster, Portland. [pp. 12, 117]; 1916, second edition, J. K. Hall, Portland. [pp. 10, 135]; 1926, third edition, J. K. Hall, Portland. [pp. 12, 137] 
A color photograph of a string of fancy glass trade beads from Memaloose Island near The Dalles, Oregon, includes a single phoenix button, apparently a I1s. The regimental number ends in $0(10,20$, or 30$)$; it appears most likely to be 30 . At that time the string was "in possession of Oregon Historical Society," Portland; however, today there is no record of this string of beads in the Oregon Historical Museum. Nomention is made of phoenix buttons in the text so Corbly Church's (1928) article remains the earliest published text.

\section{LiVingston, MiLla}

1960 The Only Phoenix IEver Had/The Story of the Phoenix Button/The Phoenix. Michigan Button Bulletin 18(2):24. Detroit.

The Downie theory that phoenix buttons were first made for Napoleon (MacLennan 1953) is presented again. Apparently Livingston has a Ib 28 and a Is 3 . She also says that the Ib28 has "faint traces of letters on the back." If so, it would differ from any listed in Strong (1975) and thus would be unique except perhaps for those listed by Kirk (1975)

1964 Phoenix Buttons - Found Along the Columbia. Michigan Button Bulletin 22(3):1,9-11, insert. Detroit.

Strong's (1975) reference to this work is corrupt, thus it has been missed by many researchers. It contains new information about the Bushby button firm of London. Most of the comments are based on correspondence with Strong. Included with the Bulletin was a loose legal-size sheet with the much-published Strong photograph of eight types of flat buttons, plus a chart of all the regimental numbers and their occurrence in the Strong collection at that time. Readers were encouraged to list additional numbered types and send the information to Strong. Mrs. Livingston also recants her position on Napoleon as expressed in her previous article. Bonneville is misspelled.

LOCKLEY, FRED

1947 Portland Woman Tells of Button Collecting. In "Fred Lockleys Impressions," a regular column. Oregon Journal. Portland.

This column is about Nelly Church and how she got involved in button studies. She obtained her first phoenix button forty years prior. She married Carl Church in 1902 and had three sons: Corbly, Randall, and John. Corbly is misspelled as Corbel in this article. John, the youngest brother, lives in Portland and has served as an informant for this bibliography, especially concerning his family. The date of this clipping obtained from Frank Buehler is unknown, but because Fred Lockley was born in 1871 and this clipping dates ca. 76 years later, it should be ca. 1947. The information presented; however, seems to precedeC. Church(1928). Extensive searching in the newspaper subject card catalogue of the Multnomah County Library, Portland, was to no avail.

\section{McCoy, PAtrick C.}

1972 Archaeological Research at Fort Elizabeth, Waimea, Kauai, Hawaiian Islands, Phase I. Report 72-7 to Division of State Parks, Hawaii Department of Land and Natural Resources, from Department of Anthropology, Bernice P. Bishop Museum. Honolulu. [pp. 30-31]

One I3b30 button is described and illustrated. O'Brien (1970) was used as a source and thus it is concluded that Napoleon probably ordered the buttons. Another button, a I1b14, is reported (Laura Carter 1992, pers. comm.) on the opposite side of Kauai found as a necklace element in a burial. Gould (1994a, 1994b) later also lists this and additional finds in Hawaii.

McHugh, RoBIN

1987 Room One: Santa Cruz Mission Adobe. Santa Cruz Archaeological Notes 16(9):12-20. Santa Cruz, CA. [pp. 14, 16]

This note contains the brief mention of two buttons, a large and a small, with a line drawing of the former (cat. no. P627-385-29), probably a I2b27 from this California site. See also Bourdeau (1985) and Schumacher(1985).

\section{MacLennan, William}

1953 Restorer of the Missions. Westways 45(10):20-21. Los Angeles. Excerpts reprinted in 1956 as French Military Buttons. Just Buttons 22(3):30-31. Hartford, CT.

Apparently this is the primary source that presented the unsubstantiated and unlikely theory of Harry Downie, that phoenix buttons were made for Napoleon (by an English firm!) and after his exile they were bought by Christophe of Haiti. One I1b5 is illustrated from the Harry Downie collection from the Carmel Mission or Mission San Carlos de Borroméo, California. The author's name is spelled McLennon in Strong (1974, 1975). The Just Buttons reprint has a photo with three types: Ilb7, I1s14, and I1 s26. See also Pilling (1950).

MiNOR, Rick

1989 A Note on Phoenix Buttons from the Aldrich Point Site (35CLT37), Clatsop County, Oregon. Manuscript, Heritage Research Associates, Inc., Eugene, OR.

This is a brief description of four buttons in the Smithsonian Institution collections from the lower Columbia River. The four include: I1b6, I1b27, I1b29, and IIb2. The last button is described as having a border which would 
suggest that it is a style 1 , thus a II 1b2. See also Adam (1968).

1989 Preliminary Inventory of the Carty Artifact Collection, Ridgefield National Wildlife Refuge. HRA Letter Report 89-5. Heritage Research Associates, Inc., Eugene, OR.

A private collection from the Cathlapotle Village site, near Ridgefield, Washington, was donated to the U. S. Fish and Wildlife Service. Included among the 25 phoenix buttons are: I1b-1, 2, 5(2), 6, 26, 27; I1 s-4, 5, 6(2), 8, 27(2), ?; I2s-23?(2), 29(5); I3b14; II1b1; and II2b1.

\section{Minor, Rick, Kathryn Anne Toepel, and Stephen Dow} BECKHAM

1985 An Overview of Investigations at 45SA11: Archeology in the Columbia River Gorge. Heritage Research Associates Report No. 39. Eugene, OR. [pp. 143, 150151] Reprinted 1989 with extensive additions as Heritage Research Associates Report No. 83. Eugene, OR. [pp. 146-147, 149]

An undisclosed number of phoenix buttons was recovered at 45SA11 near North Bonneville, Washington. This is not the site report but an overview contracted for by the U. S. Army Corps of Engineers because the original contract excavators were unable to complete a detailed final report (Skinner 1980). One illustration shows a I1b4 (cat. no. X80-14M) and five specimens have been cleaned in the metal preservation section of the Alfred W. Bowers Laboratory of Anthropology, University of Idaho. These five buttons are: I1b1 (L141-214M), I1b27 (N122-271M), I1s5(2) (X59-83M \& unknown number), and I1b28 (K139-27M). A more recent review of the collection by Rick Minor (1991, pers. comm.) verified all except the unknown number and the last one listed. Also N122-271M is apparently a I2b27, not a I lb27. The three large verified buttons are all missing their shanks and have a hole drilled near the edge for suspension.

NeILL, Wilfred T.

1968 Mystery of the Phoenix Buttons. Relics 2(2):4-5. Austin, TX.

This popular summary of various sources, with Strong predominating, has illustrations of five buttons: I1b27, I1s2, I1 s25, IIIb, and II2s2. Neill states that specimens have been found in the Great Plains but gives no specifics. Perhaps his source was Colwell (1963).

Nelson, Bruce

1973 Bob Wiles' Collection of Indian Lore. Seattle Times, Sunday Pictorial Section p. 11;25 December. Seattle.
A pothunter since 1963, Bob Wiles, who at the time of the article worked and perhaps lived in Salkum, Washington, claims to have 79 phoenix buttons of unknown provenience. It also includes a brief summary of the Strong (1960) thesis on the origins of phoenix buttons in the Pacific Northwest. The Seattle Times was published at this time without volume and issue numbers.

Nelson, Charles M.

1969 The Sunset Creek Site (45-KT-28) and its Place in Plateau Prehistory. Washington State University, Laboratory of Anthropology, Report of Investigations No. 47. Pullman. [pp. 94, 239, 416-417]

A U. S. Army general service button of the line eagle device type, Johnson (1948:[I]65-66) number 261, 262, or 263 , is illustrated and repeatedly called a phoenix button, which it is not. This site, on the Columbia River in central Washington, is beyond the normal limits of phoenix button distribution.

O'Brien, Gene

1970 Phoenix Bird Buttons. Just Buttons 28(8):201-206; 28(9):237-241. Hartford, CT.

This work was published under the name, Mrs. John J. O'Brien. Although there is very little new or startling, she does show a good command of the literature. She mentions reading one theory that the buttons came from a shipwreck at the mouth of the Columbia River; if so, it is an unknown source not in this bibliography. She agrees with the conclusion that Strong was in error when he mentioned Calver and Bolton (1950) in connection with Nelly Church and phoenix buttons. In spite of her good knowledge of the literature, she still clings to the Downie theory involving Napoleon (MacLennan 1953). She also uses Nelly Church's unsubstantiated figure of 600,000 phoenix buttons having been manufactured. This source is filled with misspelled words, especially place names. It has four illustrations of buttons including one with three views of a type III with "Bushby/London." This may be one of the buttons contained in the collection purchased in London by the well-known British Columbia anthropologist, Charles Hill-Tout(1858-1944)(p. 201). The one illustration includes: I1b8, I2b27, I3b30, and II $3 \mathrm{~b} 2$.

\section{OREGONIAN}

1963 200-Pound Carved Rock to Go on Display at Oregon Archaeological Society Show. Oregonian 102(38,176):(Sec. 2)9; 9 September. Portland.

This brief mention of the basic Strong theory on the origin of phoenix buttons includes an illustration of a I1s27. The issue number of 38,176 is correct. 
1975 Artifacts Found at Trojan Site. Sunday Oregonian 93(45):D2; 12 October. Portland.

This brief article mentions the four buttons reported in Warner and Warner (1975).

Orndoff, G. D.

1973 Rogue River Trade Goods Find. Screenings 22(3):2. Portland.

Nineteen buttons were discovered 4 June 1972 by the author and son Mike along with numerous beads of native and trade origin attached to a "buckskin shirt or breastplate." Stains and holes in the leather indicated that at least another five buttons, not necessarily phoenix, were lost. As can best be determined from one of the two crude drawings, the buttons included: Ilb-1(2), 4(2), $5,6(2), 8(2), 9(2), 26(3), 27(2), 28,29$; IIb2; and one plain brass non-phoenix.

Phebus, George E.

1978 The Smithsonian Institution 1934 Bonneville Reservoir Salvage Archaeology Project. Northwest Anthropological Research Notes 12(2):113-177. Moscow, ID. [pp. 133, 135]

This brief summary of the 1934 work of Herbert W. Krieger behind Bonneville Dam, Washington and Oregon, reports 83 phoenix buttons found on Sullivans Island, near North Bonneville, Washington, now under the backwaters of the dam. Four buttons are illustrated: I1b8, I1s8, I1b10, and I1b20. The first and last specimens are drilled for suspension. This collection, formerly in the Smithsonian Institution and since reburied by the Yakama Nation, was of little value because approximately half of the specimens were illegible from the effects of burning. The burning was not from cremations but probably from when burial sheds were fired by white settlers complaining of the odors coming from the island. Frank Buehler (1991, pers. comm.) suggests that the destruction may have been the work of the military from nearby Fort Lugenbeel. He has also observed the recovery of numerous small, burned phoenix buttons from Sullivans Island. See also Strong (1959).

Pilling, Arnold R.

1950 The Phoenix Button in California. Five page typescript and 42 note files in the private papers of Arnold R. Pilling, Wayne State University, Detroit. Copy also on file, Pacific Northwest Anthropological Archives, Alfred W. Bowers Laboratory of Anthropology, University of Idaho, Moscow.

This is the beginning of a detailed article on phoenix button distribution and history in the state of California. It includes extensive correspondence with other researchers and collectors. Several collections of phoenix buttons are described and located as of 1950 or earlier. These include the following listed sites, in the manuscript or in the indicated notes, that are not discussed in detail under other authors in this bibliography. These paragraphs are an attempt at logical order and have no relationship to Pilling's note numbers. They often encompass more than one note: 1. Carmel Mission or Mission San Carlos de Borroméo from the Harry A. Downie collection including: Ib4, Ilb5 (illustrated in MacLennan 1953), Ib6, Ib25, Ib25, Is4, Is6, Is28, Is30, and IIIb2.

2. Same site, the James Martin collection, which contained: Ib14 and Ib26.

3. Monterey, James Martin collection containing: I1b14, I2b26 (could be a I2b27 from Note 35), I1s2, I1s5, and I1s26 (2).

4. La Purísima Mission, near Lompoc; California State Parks collection: Ib9 (cat. no. 5004), I1b7 (5005), Ilb14 (4006), and I1s10 (5008).

5. James Goethe Adobe, Sonoma, Jones excavations of 1947-48: Ib27 (also details in Note 27).

6. Santo Domingo, Baja California, Mexico: Ib8.

7. San Fernando Mission.

8. Note 14-Santa Inés Mission, Site No. 4-Sba-518: Ilb10 (Hearst [formerly Lowie] Museum cat. no. 1120435 [verified 1992]).

9. Note 43-Santa Inés Mission, found by Pilling 22 August 1950: Ib6.

10. Note 14-Visalia, California, grave found in 1928, six miles east of Visalia on the Broder Place (Note 40). 11. Note 22-San Juan Bautista. See Farris (1991a, 1991b).

12. Note 21-Miwok area, Hearst [formerly Lowie] Museum cat. no. 1-71844. Pilling's notes indicated some question about the identity of this button. Determined in 1992 not to be a phoenix button.

13. Note 24 -Sprague River, Oregon: Ib2, Ib28, and another three or four. The exact location is unknown, but since the note says "up the Sprague River," we can assume that it is only in the general vicinity of the town of the same name.

RinToul, WiLliam T.

1965 Legacy of a Lost Lake. Westways 57(1):25-26. Los Angeles.

Nothing new or valuable is presented. It includes one illustration of a I1b2 button from the Southwest Museum, Los Angeles, "similar to those found at the site of the Tulamni village on the Buena Vista Lake," California. It is not clear from the text if this is the same site as Elk Hills (Walker and Woodward 1947) but locational information suggests that Elk Hills is a short distance to the north. One of these sites, most likely 
Elk Hills is probably Woodward's(Heizer 1951) “lower San Juaquin Valley," California site.

\section{Ross, Lester A.}

1976 Fort Vancouver 1829-1860, A Historical Archeological Investigation of the Goods Imported and Manufactured by the Hudson's Bay Company. Manuscript, Fort Vancouver National Historic Site, Vancouver, WA. [pp. 603, 605-606]

This summary of the 1970-1974 work at Fort Vancouver, Washington, by the National Park Service presents a table of types for the eleven buttons recovered, illustrates one, and makes important conclusions concerning the source of the buttons. The types recorded are: I1bl; I1 s-4, 5, 9, 14, 27, and 28; I2s29; and I3b?. Two buttons appear to be missing from the table. All buttons were found in a post-1834-1836 context. Ross (1976:606) says:

All come from the eastern fort area which was developed after 1834-6, and the majority came from the area around the ca. $1843-4$ to $1852-3$ Second Indian Trade Store. This suggests that items were first available around the mid 1830 's, continued in use during the mid-1840's and were probably attached to uniforms, and if Wyeth had brought them to the Northwest as trade goods, they may have become the property of the HBC along with the other goods bought by the Company when Wyeth quit the trade. No evidence has been found of these buttons on HBC invoices or inventories, so it is dubious that the Company itself imported them from Great Britain.

Additional work by Lester A. Ross also did not show Bushby as a firm with whom the Hudson's Bay Company did business. Other Fort Vancouver sources include: Caywood (1955), Hoffman and Ross (1975), Storm (1982), Thomas (1987), and Thomas and Hibbs (1984).

Sanders, Judith A., Mary K. Weber, ANd David R. BRAUNER

1983 Willamette Mission Archeological Project: Phase III Assessment. Department of Anthropology, Oregon State University, Anthropology Northwest No. 1. Corvallis. [pp. 72-73, 75]

One button was recorded at the Willamette Mission of Jason Lee (35MA5001), approximately ten miles south of Salem, Oregon, on the Willamette River. One drawing clearly shows that it is a Ils 26 .

SAUTER, JoHN, AND BRUCE JoHNSON

1974 Tillamook Indians of the Oregon Coast. Binfords \& Mort, Portland. [pp. 136-137]

Phoenix buttons reputedly from the Tillamook, Oregon, area are mentioned and illustrated. They summarize the basic material of Strong without reference. Two buttons from the collection of Wayne Jensen are illustrated and include: I1b2 and I1s1. The authors also claim to have five specimens but fail to describe them.

Schumacher, Paul J. F. (COMPILER)

1985 Phoenix Button. In 'Pacific West,' in "Current Research," pp. 19-20. Society for Historical Archaeology Newsletter 18(1):13-26. Williamsburg.

This is a virtually identical reissue of Bourdeau (1985) concerning site CA-SCR-24. See also McHugh(1987).

\section{SCREENINGS}

1954 A brief and untitled paragraph. Screenings 3(7):3. Portland.

Oregon Archaeological Society members Frank Wilke and Emory Strong found a cache of trade goods including 26 phoenix buttons near Bingen, Washington.

Seaman, N. G.

1946 Indian Relics of the Pacific Northwest. Binfords \& Mort, Portland. [pp. 60-61]

The author's full name is Norma Gilm Seaman, which may explain his use of N. G. This popular book for relic collectors contains a brief and not too informative paragraph with a photograph of a I1b6 and a I1s5. Correspondence with Pilling (1950:notes 26 and 28) clearly indicates that Seaman was holding back information for a proposed publication on Columbia River trade goods. This work did not reach maturity but the next edition (see below) did contain a chapter with that title. His publisher indicated that the trade goods manuscript did not contain enough material for a second book but when the rights to the first book were purchased from Seaman's widow by the publisher, the manuscript was added to the second edition as a new chapter. Seaman told Pilling (1950:note 28) that he gave all of his phoenix buttons, a cache of 220 , to Nelly Church.

1967 Indian Relics of the Pacific Northwest. Second edition. Binfords \& Mort, Portland. [pp. 117, 249-251]

This second edition, contains more information on the history of the origin of phoenix buttons and some on the distribution of finds but nothing new. The source of this additional material is explained above under the first edition. The final page states that "one is even reported from southern California." In light of Pilling's correspondence, this is a strange statement unless 
Southern (Baja) California is meant, as previously suggested by Strong, Schenck, and Steward(1930:65). Perhaps these are the publisher's words, rather than Seaman's.

\section{SKINNER, S. Alan (COMPILER)}

1980 Clah-cleh-lah: An Archaeological Site at Bonneville Dam, Washington. Report to Portland District, U. S. Army Corps of Engineers from Environmental Consultants, Inc., Dallas, TX. [p. 233]

This work includes only the mention of large and small buttons having been found. For details see Minor, Toepel, and Beckham $(1985,1989)$.

\section{Slaymaker, Charles}

1974 Fidemo, the Twilight, and Before, A Study of Coast Miwok Political Organization. Unpublished Master's thesis, Department of Anthropology, San Francisco State University, San Francisco. [pp. 382, 569]

At [4] Mrn-138, just north of Mission San Rafael near Marinwood, “a bronze button of the 'Phoenix' type was found which indicates a possible 1820-1830 distribution." The very poor illustration labels the artifact as 2804 MAPOM but lacks details of size and number. Von derPorten (1973:52) presents an infinitely better illustration of the same button, a I1s10.

1977 The Material Culture of Cotomko'tca. Miwok Archeological Preserve of Marin, MAPOM Papers No. 3. San Rafael, CA. [pp. 164, 267]

The site of 4-Mrn-138 in Marin County, California is described again in much the same way as above with the same poor drawing.

SPRAGUe, RoDERICK

1989 Help Needed with a Bibliography of Phoenix Buttons. Screenings 38(6):1. Portland.

A plea for help with this bibliography was directed to the membership of the Oregon Archaeological Society. The help from Frank Buehler was a direct result of this notice. The title is the journal editor's.

Stephenson, Robert L., J. David Miller, and Robert L. OGLE

1973 The Jesse Kirk Button Belt. Institute of Archeology and Anthropology Notebook 5(3):75-104. Columbia, SC. [p. 96, 101, 104]

The one phoenix button among the 120 metal specimens on this unprovenienced Klamath or Modoc ethnographic object was a I1b4. It includes one small but clear photograph of the entire belt and one of the phoenix button.

STORM, JACQUELINE M.

1982 The Buttons, 1975. In "Kanaka Village/Vancouver Barracks 1975," by David H. Chance, pp. 51-68. University of Washington, Office of Public Archaeology, Reports of Highway Archaeology No. 7. Seattle. [pp. 51-52, 61]

One button was recovered in Kanaka Village, the American Indian and Hawaiian (Kanaka) village adjacent to Fort Vancouver, in Vancouver, Washington. It apparently was a Ib25. See Ross (1976) for additional Fort Vancouver area references.

STRONG, EMORY

1956 Cremation Artifacts. Screenings 5(9):4. Portland.

While redigging a cremation pit near North Bonneville, Washington, Strong found 20 phoenix buttons around the edge of the pit. He listed only the regimental numbers which were: $1,5,6,7,8,9,14,20,25,26,27$, 28 , and 29 . Logically there must be more than one of some numbers.

1958a The Phoenix Button. Screenings 7(2):1-3. Portland.

This, the first article devoted strictly to buttons by the ultimate authority on phoenix buttons, is of more value to the history of Northwest studies of this artifact than for any scientific value. Several finds are mentioned: 1) over 200 buttons were found at some past date by Ralph and Dale Jones at the mouth of the Cowlitz River, near Kelso, Washington; 2) the well known Clackamas burial find of 40 buttons near Gladstone, Oregon, found by two boys in 1895 [apparently ancestors of Nelly Church]; 3) 26 buttons were found by Howard Galbraith, an amateur excavator, on the Multnomah Channel of Sauvies Island in the Portland area ("half that number or 13" [Frank Buehler 1991, pers. comm.]); and 4) the finding of a single button on Sauvies Island. Private collections included Nelly Church who "once had the most," Don Gallagher had 55, Frank and Elmer Buehler had 10 (considerably more today), and the author, Emory Strong, had 57. A photograph of eight buttons of undisclosed origin is used and appears again and again in subsequent publications by Strong and others. The buttons include: I1b27, I2b29, I3b?, I1s25, I2s29, and IIs2. Also illustrated are a II1 b1 and a II2b1. It should be noted that from this publication through his 1968 work the artillery button with the 
cannon and mortar is called style 4 rather than type II as he later uses (Strong 1975) and is used herein.

1958b More on Phoenix Buttons. Screenings 7(10):4. Portland.

As a follow-up to the previous article, Strong explains that he assumed he had not seen examples of the "ball type" of phoenix button but upon cleaning some plain ones he discovered not only the phoenix design but the back marking of "Bushby-London." He also mentions the uniform in the Tippicanoe County Museum, Lafayette, Indiana, with the silver plated ball- or bullet-type buttons later defined as type III (Strong 1975).

1959 Stone Age on the Columbia River. Binfords \& Mort, Portland. [pp. 214-219]

Strong's 1958 articles were updated and placed in his book on pothunting along the Columbia River. He estimates that over 100 buttons were recovered from Sullivans Island near North Bonneville, Washington. This estimate probably does not include the 83 found by Herbert W. Krieger in 1934(Phebus 1978:133) because Frank Buehler (1989, pers. comm.) can account for approximately 230 buttons in private collections. The same 1958 illustration is used plus one showing three views of a type III.

1960 Phoenix Buttons. American Antiquity 25(3):418-419. Salt Lake City. Reprinted 1967 as an Appendix to "Indian Trade Goods," by Arthur Woodward; Oregon Archaeological Society, Publication No. 2, pp. 29-30. Portland. Reprinted 1986 without authorization as The Enigma of the Phoenix Button (Part 2), Skamania County Heritage 15(3):3-5. Stevenson, WA.

This is the first publication in a professional archaeological journal of Strong's basic thesis concerning the origin and his typology of phoenix buttons. He openly rejects the Downie thesis that the buttons were first produced for Napoleon (MacLennan 1953). This is also the clearest presentation of the evidence that the buttons were brought by Nathaniel Wyeth, a theory first advanced by Corbly Church and N. G. Seaman. The same illustration of eight buttons used in the two previous publications, is used again. See Strong (1975) for Part I of the 1986 reprint and Crawford (1986) for the 1986 reprint Preface. The 1986 reprint lacks the references cited section and the illustration caption.

1965 New Phoenix Button. Screenings 14(6):1. Portland.

This one-paragraph update is the result of the Livingston (1964) article and insert. It includes a picture of three type III buttons which, until his 1975 publication, are not called type III but simply ball- or bullet-type buttons, in contrast to disk-type.

1968 Phoenix Buttons. Hobbies 73(1):50-51, 92, 98. Chicago.

A popular article that includes a few new ideas. Strong has changed his estimate of buttons found from less than a thousand to more than a thousand (eliminating all possible duplication, this bibliography can account for a minimum of 1025). For the first time Canada is mentioned as a place of discovery but is not mentioned in his next major publication (Strong 1975). No buttons are reported from Canada in any source in this bibliography. The usual eight button photograph as found in previous articles is used again plus one illustration of three examples of type III buttons. The article mentions a wreath back-mark described to Strong by William Louis Calver, however, phoenix buttons are not mentioned in Calver and Bolton (1950).

1972 More on the Phoenix Button. Screenings 21(12):2. Portland.

A button, of unknown provenience and owned by a collector in Corvallis, Oregon, is described as having a figure of a crown and "best quality" on the back around the loop. There are high quality pictures of both the front and back of this unusual I3b5. Strong also mentions an $\mathrm{s} 7$ with a wreath on the back located at the American Museum of Natural History. Both the AMNH button and the one illustrated in this article are later found in Figure 7 of his final article (Strong 1975:77).

1974 Enigma of the Phoenix Button. Manuscript, early draft of "The Enigma of the Phoenix Button." Pacific Northwest Anthropological Archives, Alfred W. Bowers Laboratory of Anthropology, University of Idaho, Moscow.

This is the same manuscript as originally submitted to Historical Archaeology and published there in a different form as Strong (1975). It contains some local historical data deleted from the published version. For example, Strong states that research began in 1905 when a string of beads with a phoenix button from an Indian burial site on the Clackamas River near Oregon City was given to the infant son of Nelly Church by his grandmother. Apparently Strong is mixing generations because Nelly, born in 1885, was the child given the buttons, while Corbly, her son, was born in 1905. See also Church (1928), Axford (1937), and Woodward and Beals (1980). 
1975 The Enigma of the Phoenix Button. Historical Archaeology 9:74-80. Columbia, SC. Reprinted 1986 without authorization as The Enigma of the Phoenix Button (Part 1), Skamania County Heritage 15(2):111. Stevenson, WA.

This is the final and most complete work of Emory Strong (1903-1980), the major authority on phoenix buttons. Also it is the first published version of his new and final type and style designations. The excellent illustrations include: types I, II, and III; the back of a flat variety; the back of type III showing "Bushby/London"; three of the four extant back-marks with corresponding fronts; a chart of known types by regimental number (see McCoy 1972 for an added type); a sketch of King Christophe of Haiti; a Haitian coin; and a Haitian sword buckle. Any study of phoenix buttons should begin with this work and any type and style designation must be based on this publication. Locations not mentioned previously are New Mexico and Florida; however, Canada, now missing, was expressly excluded in the original manuscript listed above. The references cited section contains major errors of commission and omission in the first five of the eight references. Note especially the misspelling of MacLennan (1953) and the lack of a title or volume number for Livingston (1964). See Strong (1960) for Part 2 of the 1986 reprint and Crawford (1986) for the reprint Preface. The reprint lacks the Acknowledgements and References [Cited] but has an added picture of a military uniform with Type III buttons, probably the uniform in the Tippicanoe County Museum, Lafayette, Indiana(Strong 1958b).

\section{Strong, William Duncan, W. Egbert Schenck, AND JULIAN H. STEWARD}

1930 Archaeology of The Dalles-Deschutes Region. University of California Publications in American Archaeology and Ethnology 29(1):1-154. Berkeley. [pp. 64-65, Plate 11]

This is the earliest mention of phoenix buttons coming from a scientific archaeological excavation. Alternative but very unlikely theories are presented to account for the occurrence of phoenix buttons in The Dalles area on the lower Columbia River. A footnote written after the text was in press notes the C. Church (1928) article and theory. Strong, Schenck, and Steward reported five buttons from a burial on Millers Island approximately ten miles up the Columbia River from The Dalles. The buttons included: Ib4 (cat. no. 2-12820), Ib?20 (212821) (illustrated), Ib28 (2-12822), Is? (2-12823), and Is5 (Pilling [1950] says that the final example is a Is6 [2-12824]). Excavation was by the University of California, Berkeley and the artifacts were deposited in the Lowie (currently Hearst) Museum. They could not be located in the museum in 1992, thus the full designations and the ambiguous statements could not be clarified. Additional button locations are listed, including: Indian graves near Astoria, Oregon; "several Portland museums"; DeYoung Memorial Museum, San Francisco; American Museum of Natural History, New York; and Santo Domingo, Baja California, Mexico (Is8). Jack Williams (1994, pers. comm.) suggests that this last item may have been the result of the Baja California Mission Survey.

THOMAS, BRYN

1987 Archaeological Testing and Data Recovery Excavations for a Proposed Utility Corridor at Fort Vancouver National Historic Site. Eastern Washington University Reports in Archaeology and History No. 100-57. Cheney, WA. [pp. 124, 205-206]

Two phoenix buttons were recovered, one, which apparently is a I1s4 (cat. no. 3938), is sketched. See Ross (1976) for additional Fort Vancouver area references.

Thomas, Bryn, ANd Charles HibBs, JR.

1984 Report of Investigations of Excavations at Kanaka Village/Vancouver Barracks, Washington, 1980-1981. Report to the Washington State Department of Transportation from Eastern Washington University, Cheney, WA. [Vol. 1; pp. 231, 234, 236]

One button was found in Operation 14. The text, with one sketch, indicates that it is a I1s8. For additional Fort Vancouver area references see Ross (1976).

ThOMPSON, Peter

1968 Oregonotes: What Were the "Phoenix Buttons" in Oregon History? Oregon Journal 66(269):10; 18 January. Portland.

This was a regular column always of one paragraph on the editorial page. This one is remarkable for its terse presentation of so much misinformation. Obviously it is plagiarized from Corning (1956). Jensen(1968) was written in response to this item.

TROSPER, HELEN

1965 Flight of the Phoenix Bird. Western Collector 3(5):14. San Francisco.

A brief and highly confused article ascribing to the Napoleonic origin of phoenix buttons as proposed by Downie (MacLennan 1953). It states that most phoenix buttons come from California. She reports the find of a button from low tide on Bodega Bay, California. The illustrated button appears to be a I1b5. Finds from several California sites are reported, including the previously unreported "Vallejo's Summer Home, Old Adobe, 
near Petaluma" which is actually Vallejo's Ranch headquarters in the Petaluma Adobe State Historical Monument within the California Department of Parks and Recreation(Bernard L. Fontana 1991, pers. comm.). The article was published under the name, Mrs. M. L. Trosper.

True, Delbert L.

1970 Investigations of a Late Prehistoric Complex in Cuyamaca Rancho State Park, San Diego County, California. Department of Anthropology, University of California, Archaeological Survey Monograph No. 1. Los Angeles. [pp. 44, 90-91]

A single I $1 \mathrm{~b} 4$ button was found in the cemetery area of site SDi-860. It is briefly described and well illustrated.

Von der Porten, Edward P.

1973 "Drakes Cup"? Historical Archaeology 7:46-53. Lansing, MI. [pp. 50, 52]

As part of a study to show comparative patination on brass objects recovered from Marin County, California, a Ils10 button is illustrated. It is cat. no. 38-2804, site 4MRN-138, on the north shore of San Francisco Bay, and held in the collection of the Miwok Archaeological Preserve of Marin. This is the same button described by Slaymaker $(1974,1977)$. This article does not capitalize phoenix but the same journal does at a later date in Strong (1975).

WALKer, Edwin F. WITH ARTHUR WoOdWARD

1947 Excavation of a Yokuts Indian Cemetery, Elk Hills, Kern County, California. Kern County Historical Society, Bakersfield, CA. Second printing 1963. [pp. $8,13,41,50-51]$

Burial F-50-A from this site produced two or three buttons. These were dug at the Elk Hills Cemetery, near Taft, southwest of Bakersfield, California by Walker (Southwest Museum, Los Angeles) and analyzed by Woodward (Los Angeles County Museum). Based on the illustration, one was a I1s5 and the other a I1s with an obliterated number. Woodward says the regimental numbers were 5, 7, and perhaps 6, but Pilling (1950:4) lists only 8 . The theory of the origin of the buttons is fairly close to Strong except for the suggestion that they were made in New England. Woodward quotes as his source a Mr. Howland Wood of the American Numismatic Society, a source also used by Strong, Schenck, and Steward (1930). It would be interesting to know if Wood were aware of the $\mathrm{C}$. Church article from 1928. Other sites listed by Woodward as having phoenix buttons include: Santa Barbara, California (Kirk [1975:350] says 10 were recovered); San Luis Rey Mission, California; San Juan Capistrano,
California; and Tumacacori, Arizona. The last site mentioned contained a I1b14 found in Room 50, west end, "old chapel" of Tumacacori (cat. no. DUMA 115). It was found by WPA excavators under Paul Beauties in 1934 or 1935 , was identified by Woodward in 1949, and is currently located in the Western Archeological and Conservation Center, National Park Service, Tucson (Michael J. Rodeffer 1990, pers. comm.).

WARNER, IRENE, AND GEORGE WARNER

1975 Trojan III, 35-CO-1. Oregon Archaeological Society, Report No. 7. Portland. [pp. 111-112]

Four buttons were found in 1970 by Portland State University utilizing Oregon Archaeological Society members at the Trojan site on the Columbia River six miles upriver from Rainier, Oregon. This report is concerned only with the third season of work. Emory Strong read the manuscript and advised the Warners on trade goods in 1973, yet he did not apply his own new typology (1974, 1975) to this work. The buttons were: Ib8, I1b7 (illustrated), Ib28, and IIb2. See also Oregonian (1975).

\section{WiLson, MichaEl L.}

1985 Rebirth of a Legend. Screenings 34(12):2-3. Portland.

This brief article documents the finding in Haiti of phoenix buttons identical to those found in the United States. Wilson's uncle brought back both the variety under study here as well as officer's buttons already reported in recent times from Haiti by Strong (1975:77). In addition to illustrations of the officers' buttons and 15 buttons too small to be identified, the types are clearly illustrated in a third figure which included a II3b2 and a II3s2. It is interesting that in 1949 Arthur Woodward wrote Pilling (1950:note 29) that "apparently a small cache of original buttons, mint new had turned up in an old warehouse" in Haiti. This was secondhand from "a chap, name forgotten at the moment . . ." From personal experience, it is known that Art Woodward also frequently spoke of old glass beads being found in old, unidentified warehouses around the world.

WOODWARD, ARTHUR

1959/60 Indian Trade Goods. Screenings 8(3) to 9(3). Portland. [9(2):4, 9(3):2-3]

This series of articles formed the basis for the book listed below.

1965 Indian Trade Goods. Oregon Archaeological Society, Publication No. 2. Portland. [pp. 24-27] Reprinted by O.A.S. in 1993 (after Woodward's death) as Indian 
Trade Goods in a vastly different format, with the Woodward and Strong phoenix button comments combined, and without any author listed but with copy writing by Kay L. Blocke and editing by Harvey Steele.

This whole work is based on a series of articles published in Screenings during 1959-1960 (8[3] to 9[3]). It is a brief summary of the earlier Strong (1958a) information on phoenix buttons in addition to some sites in California where buttons might have been found. Considering Strong's more recent work (1960), reprinted in this same volume, Woodward's writing is surprisingly out of date on the topic of phoenix buttons.

WoODWARD, JOHN A.

1977 A Report on the Metal Artifacts from the Mostul Cemetery, an Historic Clackamas River Indian Site. Northwest Anthropological Research Notes 11(2):155162. Moscow, ID. [pp. 155, 157, 159]

A burial site (35CL3) ten miles east of Oregon City contained four buttons which are identified by Woodward, using Strong (1959), as: I1b27, I1b28, I2b28, and IIb1.

Woodward, John A., and Herbert K. Beals

1980 Fur Trade Symbols: A Glimpse from the Gladstone Graves. In "Proceedings of the First Annual Symposium of Association of Oregon Archaeologists," pp. 97124, Martin Rosenson, editor. Association of Oregon Archaeologists, Occasional Papers No. 1. Albany, OR. [pp. 107, 111, 116-118]

Five phoenix buttons were recovered from a grave near Gladstone, Oregon, on the Clackamas River. Five buttons were in a headband or in the hair and one was part of a nose ornament. The text has all but size indicated; however, illustrations of three indicate small size for those three. The types are: I1-4, I1s5, I1-6, I1s8, I1-26, and II2s1. Another eleven specimens, contained in the Clackamas County Historical Society collection, are also reported from this site. See also Church (1928), Axford (1937), and Strong 1974.

\section{Conclusions}

A few generalizations have already developed from this preliminary examination of the literature. For example, the California specimens tend to be a few buttons in numerous domestic mission localities with the most likely use as buttons. In contrast, the Columbia River specimens occur more often in large caches or burials and were used as pendants or other forms of decoration. This functional dichotomy was first observed by Carrico (1982), but his conclusions were not published.

Julia Costello (1992, pers. comm.) disagrees and suggests that also in California the majority of the buttons were used for decoration and not as buttons. It should be noted that a great many of the Columbia River specimens have suspension holes drilled in them while none of the California buttons is described in the literature as being drilled. Furthermore, none of the Columbia River buttons is described as showing button wear patterns as described by Carrico (1982) for the San Diego Presidio.

The distribution of buttons in the two areas is also interesting. Columbia River (Figure 1) buttons range from 1 (3 sites) or 2 (1 site) to 220 (1 site) buttons with a total of 693 buttons in 23 sites or an average of 30 buttons per site. The California (Figure 2) button frequency ranges from 1 (10 sites) or 2 (9 sites) to 21 (1 site) buttons with a total of 96 buttons in 27 sites or an average of 3.6 buttons per site. Not included in the Columbia River total are another conservatively estimated 236 buttons held in local collections without provenience. Clearly we are not aware of all the factors involved in the distribution of phoenix buttons in the two areas hence the publication of this beginning effort. Carrico (1982) has pursued one possible factor in his research on coast-wise trade in California suggesting that the distribution of sites containing buttons is related to the hide and tallow trade and Mexican restrictions on trade.

There are no buttons reported, as best as current research can determine, from the following California mission sites: Santa Clara, San José, and Brancifonte all on San Francisco Bay as well as San Luis Obispo and San Gabriel. Glenn Farris (24 January 1997, pers. comm.) has suggested that this may reflect the tendency of an independent trader to avoid well fortified and tariff demanding ports in preference to the smaller coastal sites. This description of the trader would certainly fit the description of 
Strong's (1975) hypothesized importation by Nathaniel Wyeth.

Special characteristics or places of occurrence can now be identified by author. For example, back markings are discussed in Church (1928), Hobbies (1948), Strong (1958b, 1968, 1972, 1975), Livingston (1960, 1964), O'Brien (1970), and Kirk (1975). The occurrence of phoenix buttons in the Plains is not supported by the evidence yet the Plains are mentioned by Colwell (1963) and Neill (1968) and specifically Nebraska by Mr. Fixit (1950).

Of minor interest is the tradition of capitalizing phoenix. It has been capitalized in the 100 sources abstracted here with only seven exceptions that have not been influenced by drafts of this work: California Historical Society (1954), Cameron (1959), Jensen (1968), Von der Porten (1973), Hoover and Costello (1985), Farnsworth (1987), and Aikens (1993). The sources have included newspapers, books, button journals, archaeological reports, and archaeological and anthropological journals, including two articles in a journal edited by the author. Yet little or no rationale for capitalizing phoenix is now seen when it refers to a mythical bird and absolutely none when it is used as a modifier for a type of button. It is not capitalized in this bibliography except in direct quotes.

Additions and corrections are not just solicited but are welcomed and expected. Only another bibliographer can appreciate the joy of a new and obscure source or an obvious source that somehow has been overlooked for many years. It is sincerely hoped that this bibliography and suggested research questions will stimulate renewed research into this minor but intriguing trade item with its world-wide distribution including London, Haiti, Hawaii, Alaska, California, and the Columbia River drainage, especially the lower Columbia.

\section{ACKNOWLEDGMENTS}

Many people have aided in the preparation of this bibliography. First and foremost was the late Arnold Pilling who generously handed over, without any conditions, his entire file from the late 1940s and early 1950s concerning phoenix buttons in California. Harvey Steele, Editor of Screenings, the journal of the Oregon Archaeological Society, kindly published a request for information (Sprague 1989). Frank Buehler responded and generously provided several new references and verified many facts about the early Columbia River researchers. For California data, Glenn J. Farris has been a constant source of new information and verification of existing sources and site locations. Rick Minor supplied details on several lower Columbia River sites and recovered buttons. Several others have also generously provided additional data and sources; especially helpful have been Dale Archibald, Kathy Arneson, Diane Bartolle, Richard Carrico, Laura Carter, John W. Church, Ron Corbyn, Julia Costello, Steven Dietz, Lloyd L. Ferguson, Bernard L. Fontana, Steve Gould, Roberta S. Greenwood, Larry McKee, J. David McMahan, Donald P. Heldman, Michael Pfeiffer, Michael J. Rodeffer, Lester Ross, Peter D. Schulz, Linda Ferguson Sprague, the late Robert L. Stephenson, Don Sterling, Ann Troienello, Delbert L. True, Mary Vitals, George Warner, Irene Warner, Stephen F. Waylett, Priscilla Wegars, Jack Williams, and Norman L. Wilson. Thanks are also extended to the three anonymous reviewers (two forgave anonymity) for their cogent comments. Lester Ross has been especially helpful in finding the appropriate maps for locating California mission sites. The maps were prepared by Annalies Corbin. Obscure sources have been searched out by the interlibrary loan staff of the University of Idaho Library, as well as several members of the Michigan Button Society, especially Milla Livingston. The staff of the Multnomah County Library, Portland, has also aided in the continuing search for the obscure. Louise Barber provided expertise in formatting and in correcting the grammar of the final draft. All errors of omission and commission are mine alone.

Roderick Sprague 625 NORTH GARFIELD Moscow, ID 83843-3624 